\title{
The Identification Of Realistic Export Opportunities For The South African Pharmaceutical Industry
}

\author{
Wilma Viviers, North-West University (NWU), South Africa \\ Martie Lubbe, North-West University, South Africa \\ Ermie Steenkamp, North-West University, South Africa \\ Douglas Olivier, North-West University, South Africa
}

\begin{abstract}
South Africa needs to advance its industrialisation process and diversify its exports if it is to enhance its global competitiveness ranking and meaningfully tackle the double scourge of unemployment and poverty.

The pharmaceutical industry makes a significant contribution to the country's economy, and has a growing international footprint. However, export activity is largely centred on Southern and Eastern Africa, while markets in other parts of the world remain largely untapped. A longstanding concern of the government has been that export market selection has not been conducted in a scientific manner. Added to this is the problem of limited resources on the part of export promotion organisations.

A Decision Support Model (DSM), originally conceived by Cuyvers et al. (1995) and then developed for the South African environment by Viviers, Steenkamp, Rossouw, and Cuyvers (2009, 2010), was used in this study to identify those export opportunities with the greatest potential for the South African pharmaceutical industry. Through a systematic filtering and elimination process, the DSM revealed that there are a large number of export opportunities for South African pharmaceutical products, particularly in Western Europe, North America, and Africa. Such information constitutes an important basis for strategic decision making on the part of industry and government stakeholders.
\end{abstract}

Keywords: Pharmaceutical Products; Healthcare; Export Opportunities; Export Promotion; Decision Support Model (DSM)

\section{INTRODUCTION}

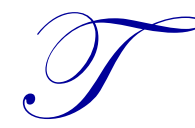

he importance of increased industrialisation, as well as the need to enhance and diversify South Africa's exports are highlighted in various national documents, for example, the National Industrial Policy Framework (NIPF) (DTI, 2010a), the South African Trade Policy and Strategy Framework (TPSF) (DTI, 2010b), and the Industrial Policy Action Plan 2 (IPAP-2) (DTI, 2011).

South Africa's National Industrial Policy Framework (NIPF) is the government's broad approach to industrialisation and was adopted by the National Cabinet in January 2007. The NIPF seeks to encourage valueadded, labour-absorbing industrial production and diversify the economy away from its current over-reliance on traditional commodities and non-tradable services, thereby creating the catalyst for employment growth (DTI, 2010a, p. 10). The implementation of the NIPF policy is set out in the IPAP-2 which was adopted by the National Cabinet in February 2010 (DTI, 2011). 
The IPAP-2 therefore also highlights the importance of extending the reach and impact of the South African manufacturing sector in order to reduce the country's current reliance on traditional commodities. One of the key components in this process is building new areas of competitiveness for different product groups by identifying growth opportunities in key export markets. In this regard, the plastics, pharmaceutical, and chemical industries are given special attention in the IPAP-2 (DTI, 2011).

The pharmaceutical industry is a key stakeholder in the healthcare field, making a significant and unique contribution on both a national and global scale. South Africa has a well-developed pharmaceutical industry, with local and multinational corporations providing medications for both primary and secondary healthcare purposes. Given the growing incidence of infectious diseases, such as HIV/AIDS, malaria, and tuberculosis, as well as lifestyle diseases, such as cardiovascular deficiencies and diabetes (Maloney \& Segal, 2007), the pharmaceutical industry has an increasingly important role to play in improving citizens' access to healthcare. In fact, this is seen as a public policy priority. There is a strong and growing demand for pharmaceutical products both in South Africa and throughout the southern African region. The question, though, is: How can the pharmaceutical industry best take advantage of this growing demand, particularly in the rest of Africa?

To enhance the export performance of South Africa's pharmaceutical industry, the export opportunities presenting themselves to the industry should be systematically explored. The first aim of this study is therefore to identify and analyse the South African pharmaceutical industry's export opportunities in different parts of the world, and specifically on the African continent. The second aim is to propose which of these opportunities, due to their high potential, should be given priority in terms of the country's export promotion efforts. To this end, the Decision Support Model (DSM), as developed for the South African trade environment by Viviers, Steenkamp, Rossouw, and Cuyvers $(2009,2010)$, is a focused market selection model designed to identify the most promising export opportunities from a large number of potential product-market combinations. At a practical level, the DSM helps the South African government and private sector to prioritise the production and export of a range of products for particular markets. The model can also be effectively applied to the pharmaceutical industry.

The results of this study will provide relevant stakeholders in the pharmaceutical industry with thorough insights into which and how many of the identified pharmaceutical products constitute realistic export opportunities in which countries, as well as the potential export value and market accessibility of each identified opportunity. The DSM thus strongly supports the government's drive to diversify South Africa's exports.

This paper is organised as follows: first, South Africa's current export climate and need for focused export promotion will be discussed, and an overview of the country's pharmaceutical industry will be provided. The methodology of the DSM, which was applied to identify export opportunities for South African pharmaceutical products, will then be described. Finally, the results of this application of the DSM will be provided, with special attention being given to the export opportunities emanating from other African countries.

\section{SOUTH AFRICA'S EXPORTS AND EXPORT PROMOTION NEEDS}

Since 1994, the achievement of economic growth through the acceleration of exports has been an acknowledged policy imperative of the South African government. However, South Africa makes minimal contribution to global growth and is responsible for only about $0.5 \%$ of world exports (ITC, 2012). Trade with the EU, a traditional trading region for South Africa, accounts for a sizeable 25\% of South Africa's total exports and $32 \%$ of its total imports (ITC, 2012). However, South Africa's growing economic co-operation with other regions offers scope for the country to expand its trading network. In particular, the dynamic economic growth patterns of many countries in the South should nourish South Africa's trade relationships with such countries which, in turn, could be a cornerstone of South Africa's diversification and industrialisation efforts (DTI, 2010a). In addition, growing the country's trade with the rest of the African continent through the SADC Free Trade Agreement is a key strategic goal of the South African government (NKC, 2012).

It is important to note, however, that although a country's exporters may have the potential to diversify their production capabilities and exports, the exporters on their own will not necessarily be able to create new areas of competitive advantage. Strong government and institutional frameworks are needed to tackle market failures and 
create incentives that encourage and facilitate new economic pursuits. In line with this process, forward-thinking trade policies can help to shift the country's dependence from commodity-based production to value-added manufacturing, and from static comparative advantages to 'new' export opportunities (that is, new export products to new markets, as well as existing export products to new markets). Such a strategic reorientation can also induce stronger medium- and high-level technological capabilities (DTI, 2010a, p. 21).

For a new export promotion strategy to be developed or existing export promotion programmes to be evaluated, hard, quantitative data are needed on a range of foreign markets. As export promotion organisations have only limited resources at their disposal, the most promising markets and product groups (product-country combinations) should be given attention. Identifying the leading export opportunities is central to this process.

However, it is stated in South Africa's National Export Strategy that the absence of a scientific method to prioritise markets and products has resulted in a 'shotgun' approach to export promotion (DTI, 2006). The challenge lies in knowing how to select and prioritise markets from the innumerable export opportunities that are scattered across the globe.

In order to assist export promotion organisations to design their promotional programmes in a more efficient and focused manner, Cuyvers et al. (see Cuyvers, De Pelsmacker, Rayp, \& Roozen, 1995) developed a Decision Support Model (DSM) for the identification of export opportunities. The DSM was first applied to Belgium (Cuyvers et al., 1995) and then to Thailand (Cuyvers, 1996, 2004). After that, the methodology was refined for South Africa in 2007, 2009, and 2010 (Viviers \& Pearson, 2007; Viviers, Rossouw, \& Steenkamp, 2009; Pearson, Viviers, Naude, \& Cuyvers, 2010; Viviers, Steenkamp, Rossouw, \& Cuyvers, 2010; Steenkamp, 2011).

The DSM was used in this study specifically to identify the export opportunities for the South African pharmaceutical industry. The approach taken and the results of the application will be covered in the remaining sections of this paper.

\section{THE SOUTH AFRICAN PHARMACEUTICAL INDUSTRY}

South Africa has a dichotomous healthcare system, comprising a public healthcare sector that often lacks the systems, skills and resources to run facilities optimally and deliver efficient services, and a well-resourced and highly skilled private healthcare sector that serves a minority of the population.

The World Health Organization (WHO) recommends that countries should spend at least 5\% of their GDP on healthcare. South Africa already spends $8.3 \%$ of its GDP on health, exceeding the WHO's recommended figure (Department of Health 2011). This $8.3 \%$ is allocated as follows: $4.1 \%$ is spent on private healthcare and $4.2 \%$ on public healthcare. The $4.1 \%$ spend covers $16 \%$ of the population ( 8.2 million people) who largely belong to medical schemes. The other $4.2 \%$ covers the remaining $84 \%$ of the population (42 million people) who are not covered by medical aid or health insurance and mainly rely on the public healthcare sector. Despite South Africa's high expenditure on healthcare, the country's health outcomes remain poor when compared with those of similar middleincome countries. This poor performance has been attributed largely to the inequities between the public and private sector.

Notwithstanding South Africa's generally poor health record, the Deloitte Report (2007) emphasised that the country's pharmaceutical market is well developed compared with other African countries. According to the Deloitte Report (2010), the pharmaceutical industry - which focuses mainly on the production of generics contributed $1.58 \%$ of South Africa's GDP in the 2008/2009 financial year. The sector's revenue that year was R36.1-billion (approximately US $\$ 4$ billion), with exports contributing R2.5-billion (approximately US\$278 million).

These impressive figures aside, the South African pharmaceutical industry faces the same challenges that the healthcare system and country as a whole are grappling with. The high prevalence of infectious diseases, such as HIV/AIDS, malaria and tuberculosis, and lifestyle diseases, such as cardiovascular deficiencies and diabetes, are placing a considerable strain on both the private and public healthcare sectors. In addition, widespread unemployment and poverty negatively affect the delivery of healthcare services (Maloney \& Segal, 2007; Deloitte Report, 2007). 
South African pharmaceutical output grew dramatically from the mid to the late 1990s (Dummett, 2002). Several multinational corporations have a presence in South Africa through local subsidiaries, and they are increasingly viewing the country as a stable base from which to access the sub-Saharan African market. In particular, they are taking advantage of the public sector's tendering process which is highly competitive and the source of huge opportunity.

Domestic manufacturers meet around one third of the country's demand for pharmaceuticals, with a higher percentage in the generics sector. The two largest South African-owned pharmaceutical manufacturers are Aspen Pharmacare and Adcock Ingram. Aspen is Africa's largest pharmaceutical manufacturer and the largest generics manufacturer in the southern hemisphere. The group - which has 18 manufacturing facilities at 13 sites on 6 continents - is represented in South Africa, Australia, Hong Kong, Philippines, Kenya, Tanzania, Uganda, Dubai, Germany, Ireland, Mauritius, Brazil, Mexico, and Venezuela. Adcock Ingram, in turn, provides an extensive range of branded and generic prescription and over-the-counter products across a wide range of therapeutic classes.

According to the UN Comtrade database, the top foreign supplier of pharmaceutical products to South Africa during 2011 was Germany, with sales valued at US\$271.85 million. Next came the United States of America and India with sales valued at US\$270.42 million and US\$264.88 million, respectively. France supplied US\$238.98 million-worth of pharmaceutical products, followed by the United Kingdom with US\$197.56 million-worth of products (ITC, 2012). In June 2010, South Africa's Minister of Trade and Industry extended an invitation to Indian pharmaceutical companies to establish manufacturing units in the country. This initiative formed part of the South African government's larger industrial policy framework (Essack et al., 2011: see also 1).

The UN Comtrade database also reveals that the South African pharmaceutical industry exported products worth US\$178.32 million in 2011. The top export destination for South Africa was the United States of America which received US\$24.25 million-worth of pharmaceutical products, followed by Kenya (US\$19.04 million-worth), Zimbabwe (US\$15.15 million-worth), Zambia (US\$12.99 million-worth), and Mauritius (US\$10.43 million-worth) (ITC 2012). In 2011 South Africa exported US $\$ 93.63$ million-worth of pharmaceutical products (or $52.5 \%$ of the total) to other countries on the African continent.

The Genesis Report (Maloney \& Segal, 2007, p. 31) asserts that the pharmaceutical industry is a strategically important player in the whole healthcare system in South Africa and has the potential to grow. However, the report further suggests that South Africa needs to decide how to direct its energies, that is (i) domestic vs. export production and development, and (ii) all products vs. a limited number of niche products and activities in the pharmaceutical value chain.

By providing information on export opportunities for South Africa's pharmaceutical industry, this study makes an important contribution to the strategic conversation taking place among private and public sector stakeholders.

\section{THE DECISION SUPPORT MODEL (DSM) METHODOLOGY}

The DSM was first developed by Cuyvers et al., (1995, pp. 173-186) in order to identify the productcountry combinations with the highest export potential for a specific country. It was designed to give export promotion organisations, in particular, a more scientific means of determining those products and destination countries that they should concentrate on in their export promotion activities.

The DSM methodology starts by considering all possible countries and products world-wide. Using four sequential filters, the DSM eliminates less interesting/promising product-country combinations with a view to categorising and prioritising realistic export opportunities (REOs) for the country to which the model is applied.

The first filter assesses all countries in terms of their political and commercial risk, and also investigates macro-economic indicators to determine whether the countries display sufficient overall market size and growth. The second filter assesses the market potential of the various product groups for the remaining countries, as reflected in the size and growth of import demand. The third filter examines the accessibility of each market by assessing the 
degree of market concentration, as measured by the Herfindahl-Hirschman index, and different barriers to entry, such as shipping time and cost, logistical efficiency, ad valorem tariffs and non-tariff barriers. It is after the third filter that a list of potential export opportunities (product-country combinations) can be extracted. Finally, the fourth filter categorises these potential export markets on the basis of South Africa's relative market share in the markets (compared with the share enjoyed by the top six competitors in the markets concerned), and the import size and growth of each of the identified markets. This categorisation is illustrated in Table 1.

Table 1: Final Categorisation of Realistic Export Opportunities

\begin{tabular}{|l|c|c|c|c|}
\hline \multirow{2}{*}{} & \multicolumn{4}{|c|}{ Market Share of Country $\boldsymbol{n}$ (Filter 4) } \\
\cline { 2 - 5 } & Relatively Small & Intermediately Small & Intermediately High & Relatively High \\
\hline $\begin{array}{l}\text { Large Product/Market } \\
\text { Term) Product/Market }\end{array}$ & Cell 1 & Cell 6 & Cell 11 & Cell 16 \\
\hline $\begin{array}{l}\text { Large Product/Market with } \\
\text { Short-Term Growth }\end{array}$ & Cell 2 & Cell 7 & Cell 12 17 \\
\hline $\begin{array}{l}\text { Large Product/Market with } \\
\text { Long-Term Growth }\end{array}$ & Cell 4 & Cell 8 & Cell 13 & Cell 18 \\
\hline $\begin{array}{l}\text { Large Product/Market with } \\
\text { Short- And Long-Term Growth }\end{array}$ & Cell 5 & Cell 10 & Cell 14 & Cell 19 15 \\
\hline
\end{tabular}

Source: Cuyvers, Steenkamp, \& Viviers (2012)

From Table 1 it is clear that a total of 20 different kinds of market are distinguished in the DSM. The exporting country to which the model is applied will therefore know what the potential (demand) in the market is (import size and growth) and the extent to which this opportunity has been utilised, based on the relative market share. If a product-country combination is classified in Cell 5 , for instance, it means that the demand in that market is high and growing over the short and long terms, but the exporting country under consideration has a relatively small share of that market.

The most recent application of the DSM on the HS 6-digit level extended the earlier methodology by calculating a potential export value for each realistic export opportunity. This was done by dividing the total imports of product $j$ by country $i$ by the number of countries that supplies $80 \%$ of these imports. This estimation of export potential gives an indication of the size of the import demand for each product-country combination relative to one another. The export potential should thus not be interpreted as a target value, but rather as a means to prioritise the export opportunities.

For more detail on the DSM methodology, and specifically how the cut-off values in each filter are determined, see Cuyvers, Steenkamp, and Viviers (2012).

\section{DSM RESULTS FOR THE SOUTH AFRICAN PHARMACEUTICAL INDUSTRY}

For this study the DSM was applied on a HS 6-digit level and a total of 31 HS 6-digit level pharmaceutical products were subject to analysis.

South Africa has exported 22 of these 31 products before. Studies have shown that existing exporters are better equipped to overcome the costs of entering export markets (Bernard, Jensen, Redding, \& Schott, 2011, p. 2). Therefore, in order to give the South African pharmaceutical industry a more realistic indication of its export opportunities, only the results of these 22 products are reported in this study.

\subsection{Export Opportunities for South African Pharmaceutical Products in the Rest of the World}

Using the DSM methodology, a total of 403 export opportunities were identified for the South African pharmaceutical industry in the rest of the world. These will now be examined on a regional, country, product, and product-country level. 
Figure 1 shows the regional distribution of export opportunities for South African pharmaceutical products. It is clear that almost half of the export potential lies in Western Europe (47.42\%), followed by North America (28.77\%), Central Europe (9.34\%), South West Europe (4.86\%), and Southern Europe (4.48\%).

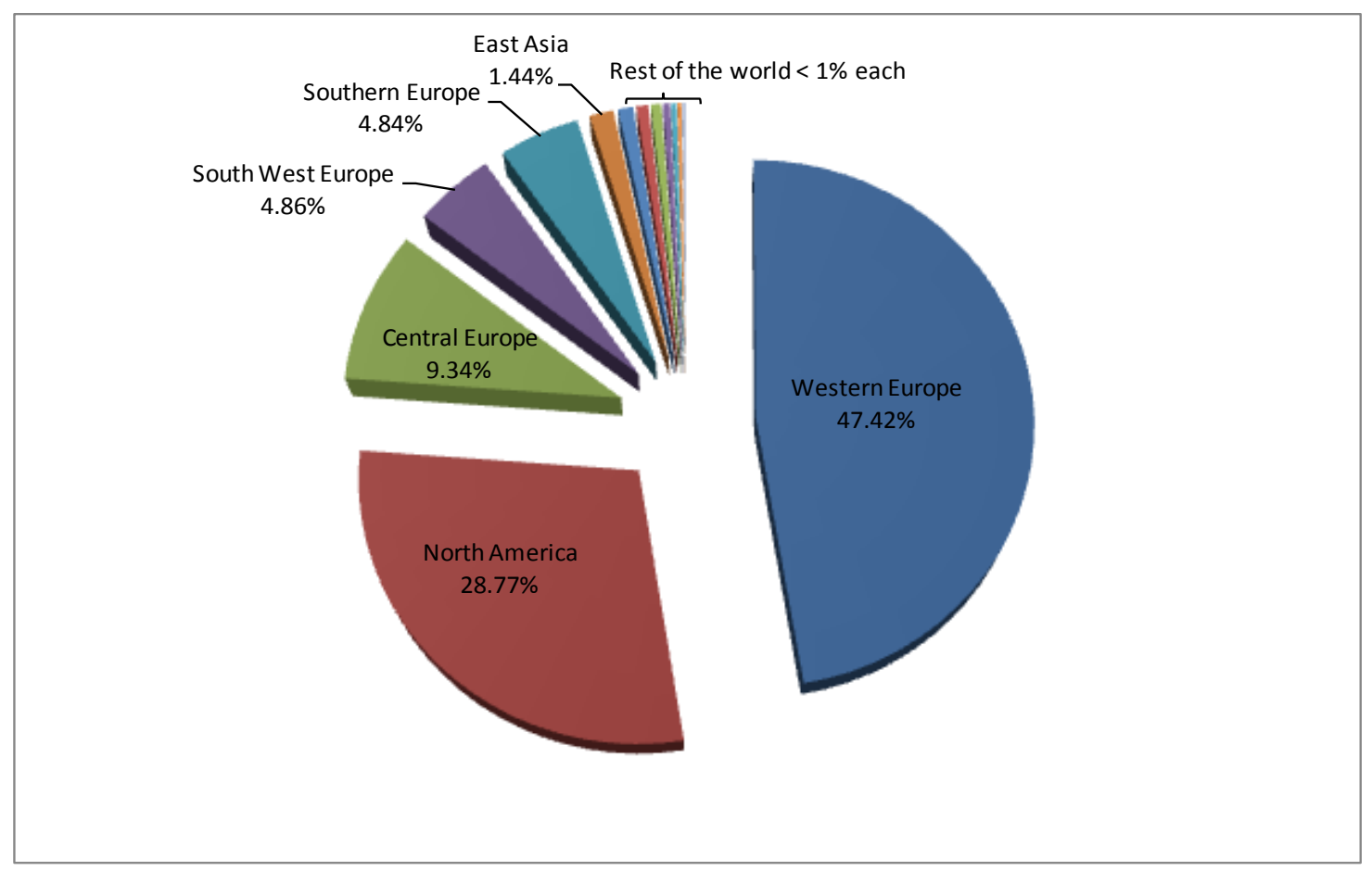

Figure 1: Regional Distribution of the Export Opportunities for South African Pharmaceutical Products

The extent to which South Africa has utilised this export potential is set out in Table 2.

Table 2: South Africa's Utilisation of the Export Potential for Pharmaceutical Products in each World-Wide Region

\begin{tabular}{|l|c|c|}
\hline Rank Based on Export Potential & Region & Utilisation of Export Potential by South Africa \\
\hline 1 & Western Europe & $0.14 \%$ \\
\hline 2 & North America & $0.04 \%$ \\
\hline 3 & Central Europe & $0.04 \%$ \\
\hline 4 & South West Europe & $0.21 \%$ \\
\hline 5 & Southern Europe & $0.01 \%$ \\
\hline 6 & East Asia & $0.02 \%$ \\
\hline 7 & Pacific & $0.81 \%$ \\
\hline 8 & South East Europe & $0.09 \%$ \\
\hline 9 & Northern Asia & $0.00 \%$ \\
\hline 10 & South West Asia & $0.27 \%$ \\
\hline 11 & South America & $0.81 \%$ \\
\hline 12 & South East Asia & $0.24 \%$ \\
\hline 13 & Northern Europe & $0.07 \%$ \\
\hline 14 & Eastern Europe & $0.04 \%$ \\
\hline 15 & Northern Africa & $0.00 \%$ \\
\hline 16 & Southern Africa & $78.66 \%$ \\
\hline 17 & Central Asia & $0.00 \%$ \\
\hline 18 & South Asia & $0.15 \%$ \\
\hline 19 & Central America & $0.00 \%$ \\
\hline 20 & Western Africa & $17.17 \%$ \\
\hline 21 & West Indies & $0.00 \%$ \\
\hline 22 & Eastern Africa & $61.70 \%$ \\
\hline
\end{tabular}


Table 2 clearly shows that in the top 10 regions South Africa has utilised the export potential for its pharmaceutical products by less than $1 \%$. Furthermore, the country is paying practically no attention to the export opportunities in Northern Asia, Northern Africa, Central Asia, and the West Indies. South Africa might have exported pharmaceutical products to these regions before but not according to the specific product-country combinations identified as realistic export opportunities. In contrast, in Southern Africa and Eastern Africa, South Africa has utilised the export potential for its pharmaceutical products by an impressive $78.66 \%$ and $61.70 \%$, respectively, (The DSM results for the African continent will be explored more fully in Section 5 below.)

Figure 2 shows the 20 countries with the highest export potential world-wide for South African pharmaceutical products, while Table 3 reveals the extent to which South Africa has utilised the export potential in the top 30 export destinations for its pharmaceutical products.

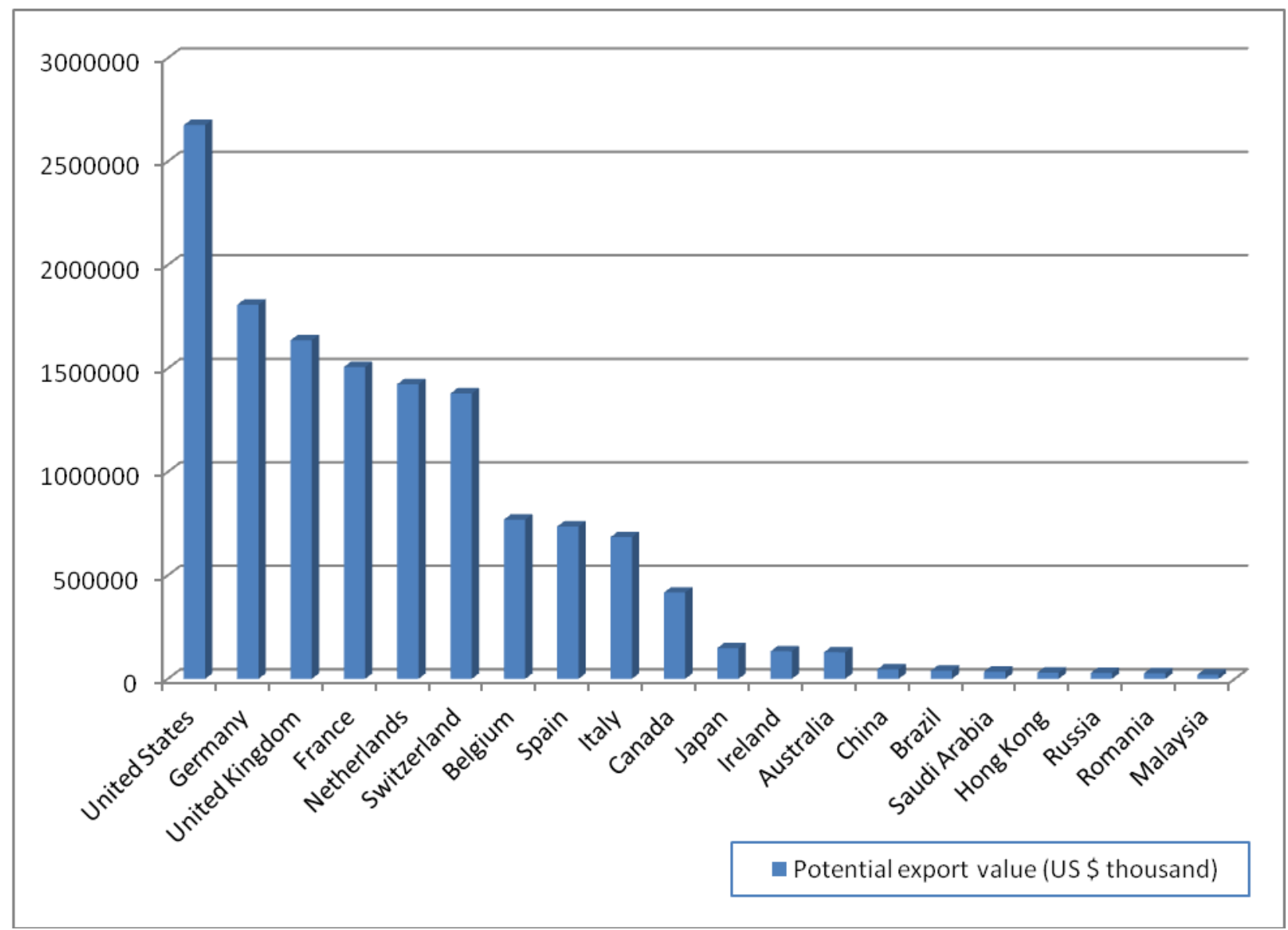

Figure 2: Top 20 Countries in Terms of Export Potential for South African Pharmaceutical Products 
Table 3: South Africa's Utilisation of the Export Potential in each of the Top 30 Export Destinations for South African Pharmaceutical Products

\begin{tabular}{|c|c|c|}
\hline \\
\hline Rank Based on Export Potential & Country & \% Utilisation of Export Potential by South Africa \\
\hline 1 & United States & $0.07 \%$ \\
\hline 2 & Germany & $0.32 \%$ \\
\hline 3 & United Kingdom & $0.39 \%$ \\
\hline 4 & France & $0.14 \%$ \\
\hline 5 & Netherlands & $0.10 \%$ \\
\hline 6 & Switzerland & $0.06 \%$ \\
\hline 7 & Belgium & $0.11 \%$ \\
\hline 8 & Spain & $0.36 \%$ \\
\hline 9 & Italy & $0.01 \%$ \\
\hline 10 & Canada & $0.28 \%$ \\
\hline 11 & Japan & $0.04 \%$ \\
\hline 12 & Ireland & $0.02 \%$ \\
\hline 13 & Australia & $1.39 \%$ \\
\hline 14 & China & $0.01 \%$ \\
\hline 15 & Brazil & $1.87 \%$ \\
\hline 16 & Saudi Arabia & $0.37 \%$ \\
\hline 17 & Hong Kong & $0.07 \%$ \\
\hline 18 & Russia & $0.00 \%$ \\
\hline 19 & Romania & $0.19 \%$ \\
\hline 20 & Malaysia & $0.08 \%$ \\
\hline 21 & Singapore & $0.56 \%$ \\
\hline 22 & Sweden & $0.00 \%$ \\
\hline 23 & Poland & $0.09 \%$ \\
\hline 24 & Thailand & $0.32 \%$ \\
\hline 25 & Egypt & $0.00 \%$ \\
\hline 26 & Zambia & $98.32 \%$ \\
\hline 27 & Greece & $0.39 \%$ \\
\hline 28 & Norway & $0.46 \%$ \\
\hline 29 & Czech Republic & $0.00 \%$ \\
\hline 30 & Slovenia & $0.00 \%$ \\
\hline
\end{tabular}

Again, North American and European countries feature in the top 10 when it comes to export potential for South African pharmaceutical products. Other promising countries in the top 20, in other regions, include Japan, Australia, Russia, Brazil, China, Saudi Arabia, Hong Kong, Romania, and Malaysia.

Overall, South Africa has utilised the export potential for its pharmaceutical products to a very limited extent. Interestingly, China, Brazil, and Russia - which are BRICS members - are among the top 20 countries as far as export potential is concerned, but South Africa has hardly tapped these markets. The BRICS grouping could be a key opportunity area for the South African pharmaceutical industry given the government's call for the country's exporters to turn their attention to BRICS and other emerging markets.

Those countries with relatively high export potential that has not been utilised at all $(0.00 \%)$ by the South African pharmaceutical industry include Russia, Sweden, Egypt, the Czech Republic, and Slovenia. This does not mean that South Africa has never exported pharmaceutical products to these countries, but rather that it has not exported the specific pharmaceutical products identified as having high export potential to these countries.

The only African country that made it to the list of the top 30 export destinations for South African pharmaceutical products is Zambia, where South Africa has utilised $98.32 \%$ of its export potential. (The DSM results for African countries will be discussed more fully in Section 5 below.) 
Figure 3 shows the 15 pharmaceutical products with the highest export potential for South Africa.

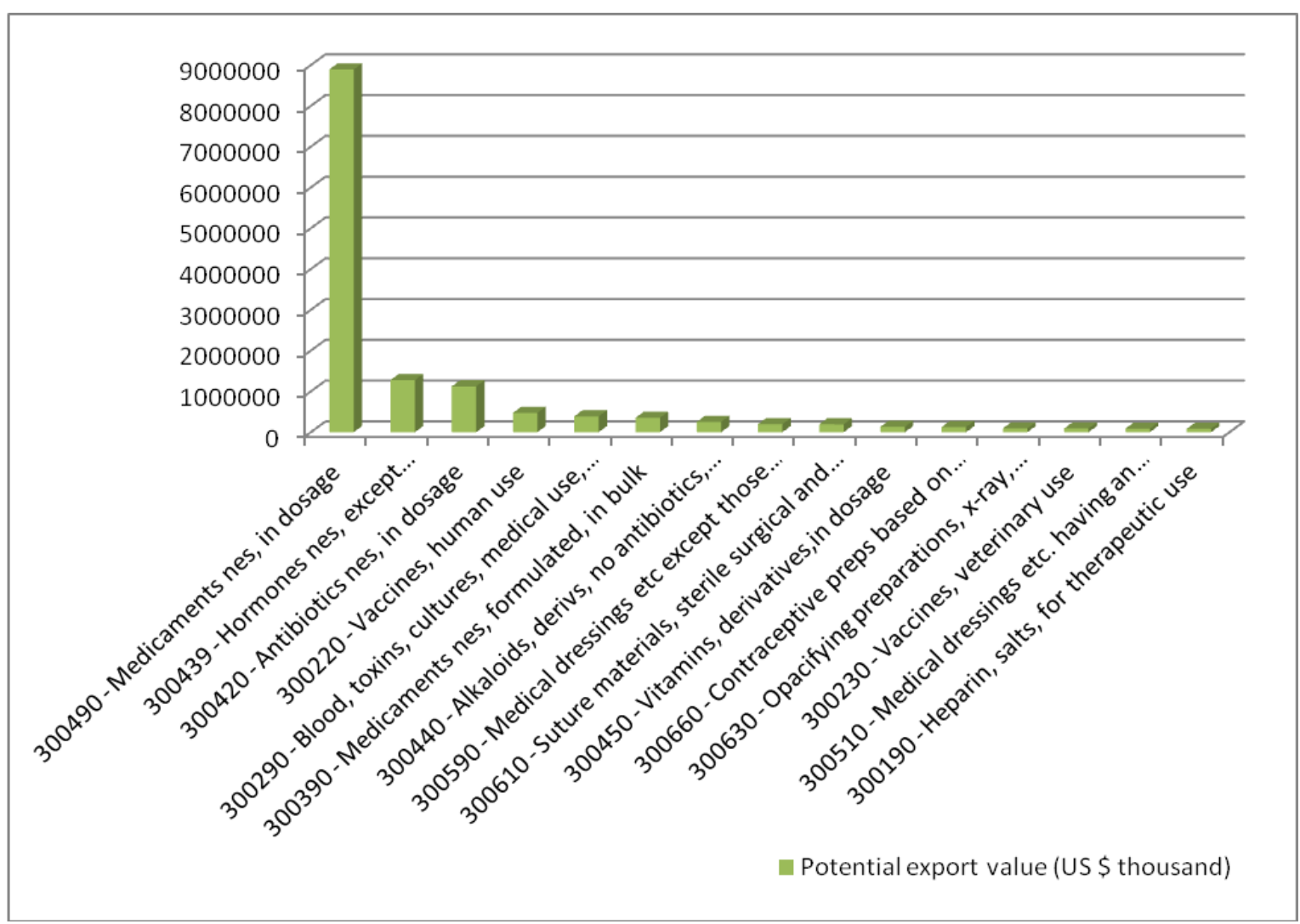

Figure 3: Top 15 Pharmaceutical Products in Terms of Export Potential for South Africa

It is clear that 'HS 300490 - Medicaments not elsewhere specified, in dosage' has, by far, the highest export potential for South Africa. This product category includes medicine consisting of products for therapeutic or prophylactic purposes in measured doses, excluding medication containing antibiotics, hormones, alkaloids, or vitamins. The high potential export value of this product category can probably be attributed to the fact that many products are classified together under this particular HS code. The DSM is applied on a HS 6-digit level because this is the highest level of product classification that is standardised across all countries. HS 8-, 10- and 12-digit classifications will provide more specific product descriptions, but these are not standardised throughout the world and different countries might use different codes for the same product.

More in-depth, market-specific studies can be undertaken to determine the products in the HS 8-, 10- or 12digit classifications with the highest export potential in each country under consideration. 
Figure 4 shows the 15 pharmaceutical products with the highest export potential for South Africa, but excludes 'HS 300490 - Medicaments not elsewhere specified, in dosage' to offer a more balanced perspective on the relative export potential of the remaining products.

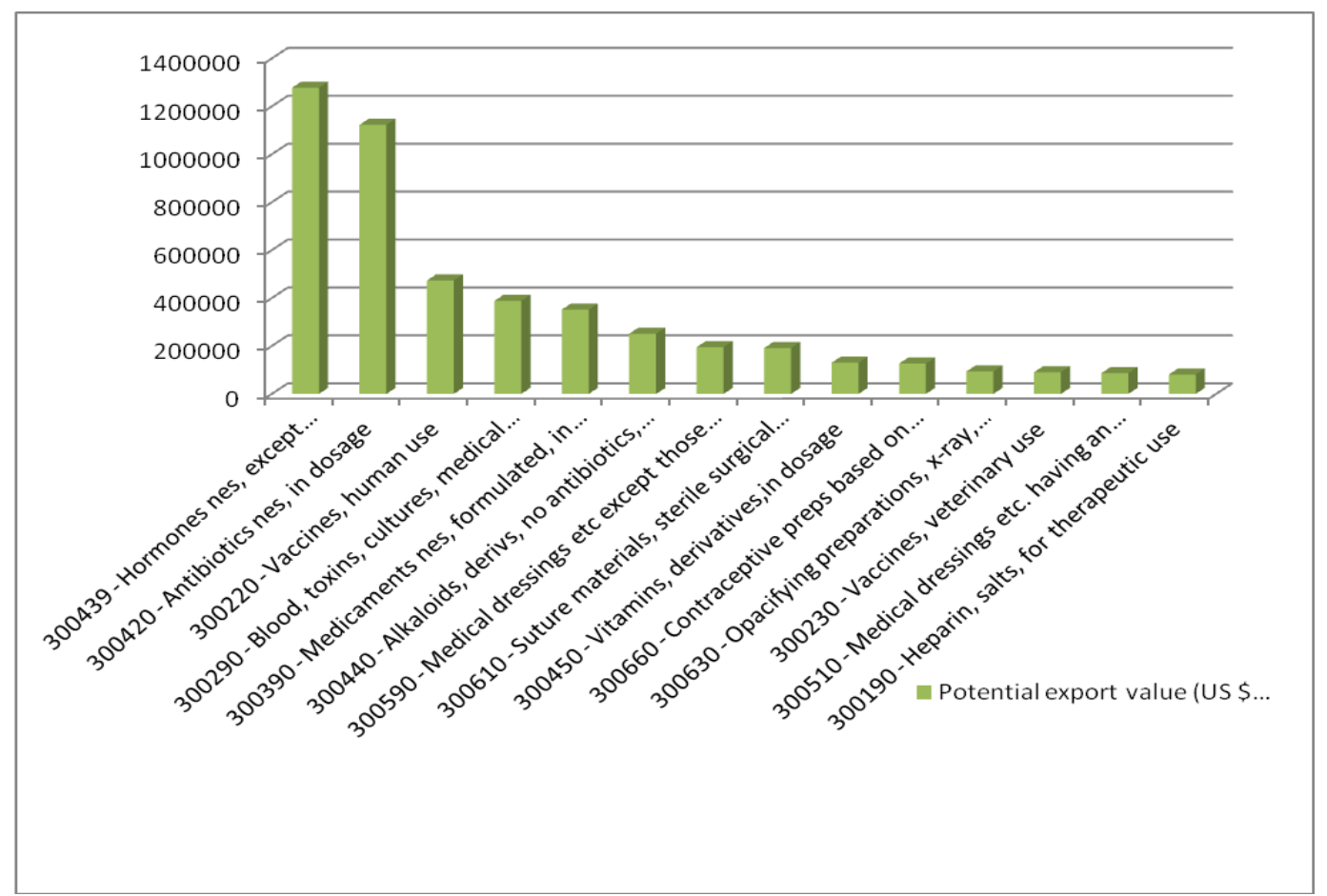

Figure 4: Top 15 Pharmaceutical Products in Terms of Export Potential for South Africa, Excluding HS 300490 South Africa.

Table 4 ranks the 22 pharmaceutical products included in this study according to their export potential for

Table 4: Ranking of South African Pharmaceutical Products in Terms of Export Potential

\begin{tabular}{|l|l|c|}
\hline $\begin{array}{c}\text { Rank Based } \\
\text { on Export }\end{array}$ & \multicolumn{1}{|c|}{ HS 6-Digit Product Code and Description } & $\begin{array}{c}\text { \% Utilisation of } \\
\text { Export Potential }\end{array}$ \\
\hline 1 & 300490 - Medicaments not elsewhere specified, in dosage & $0.21 \%$ \\
\hline 2 & 300439 - Hormones not elsewhere specified, except contraceptives, in dosage & $0.08 \%$ \\
\hline 3 & 300420 - Antibiotics not elsewhere specified, in dosage & $0.16 \%$ \\
\hline 4 & 300220 - Vaccines, human use & $0.01 \%$ \\
\hline 5 & 300290 - Blood, toxins, cultures, medical use, not elsewhere specified & $0.05 \%$ \\
\hline 6 & 300390 - Medicaments not elsewhere specified, formulated, in bulk & $0.03 \%$ \\
\hline 7 & 300440 - Alkaloids, derivs, no antibiotics, hormones, in dosage & $0.01 \%$ \\
\hline 8 & 300590 - Medical dressings etc. except those with adhesive layer & $1.93 \%$ \\
\hline 9 & 300610 - Suture materials, sterile surgical and dental goods & $0.27 \%$ \\
\hline 10 & 300450 - Vitamins, derivatives, in dosage & $0.26 \%$ \\
\hline 11 & 300660 - Contraceptive preps based on hormones or spermicides & $0.00 \%$ \\
\hline 12 & 300630 - Opacifying preparations, x-ray, diagnostic reagents & $0.41 \%$ \\
\hline 13 & 300230 - Vaccines, veterinary use & $0.70 \%$ \\
\hline 14 & 300510 - Medical dressings etc. having an adhesive layer & $9.39 \%$ \\
\hline 15 & 300190 - Heparin, salts, for therapeutic use & $0.00 \%$ \\
\hline 16 & 300320 - Antibiotics not elsewhere specified, formulated, in bulk & $0.00 \%$ \\
\hline 17 & 300650 - First-aid boxes and kits & $0.77 \%$ \\
\hline 18 & 300120 - Extracts of glands etc. for therapeutic use & $0.33 \%$ \\
\hline
\end{tabular}


Table 4 cont.

\begin{tabular}{|l|l|c|}
\hline 19 & 300620 - Blood-grouping reagents & $0.00 \%$ \\
\hline 20 & 300339 - Hormones not elsewhere specified, no antibiotics, bulk, not contraceptive & $0.00 \%$ \\
\hline 21 & 300670 - Gel preps. designed to be used in human/veterinary medicine as a lubricant... & $1.50 \%$ \\
\hline 22 & 300340 - Alkaloids, derives, without antibiotics, hormones, bulk & $0.00 \%$ \\
\hline
\end{tabular}

In respect of most of the pharmaceutical products included in this study, South Africa has utilised the export potential to a very limited extent. Only the export potential of 'HS 300510 - Medical Dressings, having an adhesive layer' has been utilised to a meaningful extent $(9.39 \%)$ compared with that presented by the other products (all less than 2\%).

Those products that the South African pharmaceutical industry has not exported to the countries identified as having the highest export potential for such products are: 'HS 300660 - Contraceptive preparations based on hormones or spermicides,' 'HS 300190 - Heparin, salts, for therapeutic use,' 'HS 300320 - Antibiotics not elsewhere specified, formulated, in bulk,' 'HS 300620 - Blood-grouping reagents,' and 'HS 300339 - Hormones not elsewhere specified, no antibiotics, bulk, not contraceptive' have not been exported by the South African pharmaceutical industry to the countries identified as having the highest export potential for these products.

To be more specific, Table 5 sets out the pharmaceutical product-country combinations with the highest export potential for South Africa.

Table 5: Top 30 Pharmaceutical Product-Country Combinations in Terms of Export Potential

\begin{tabular}{|c|c|c|c|}
\hline $\begin{array}{c}\text { Rank Based } \\
\text { on Export } \\
\text { Potential }\end{array}$ & HS 6-Digit Product Code and Description & Country & Cell \\
\hline 1 & 300490 - Medicaments not elsewhere specified, in dosage & United States & 6 \\
\hline 2 & 300490 - Medicaments not elsewhere specified, in dosage & Germany & 11 \\
\hline 3 & 300490 - Medicaments not elsewhere specified, in dosage & France & 11 \\
\hline 4 & 300490 - Medicaments not elsewhere specified, in dosage & Netherlands & 11 \\
\hline 5 & 300490 - Medicaments not elsewhere specified, in dosage & United Kingdom & 11 \\
\hline 6 & 300490 - Medicaments not elsewhere specified, in dosage & Switzerland & 6 \\
\hline 7 & 300490 - Medicaments not elsewhere specified, in dosage & Belgium & 11 \\
\hline 8 & 300490 - Medicaments not elsewhere specified, in dosage & Italy & 11 \\
\hline 9 & 300420 - Antibiotics not elsewhere specified, in dosage & Switzerland & 1 \\
\hline 10 & 300439 - Hormones not elsewhere specified, except contraceptives, in dosage & United Kingdom & 11 \\
\hline 11 & 300490 - Medicaments not elsewhere specified, in dosage & Spain & 11 \\
\hline 12 & 300490 - Medicaments not elsewhere specified, in dosage & Canada & 11 \\
\hline 13 & 300439 - Hormones not elsewhere specified, except contraceptives, in dosage & Switzerland & 4 \\
\hline 14 & 300220 - Vaccines, human use & United States & 6 \\
\hline 15 & 300390 - Medicaments not elsewhere specified, formulated, in bulk & Spain & 5 \\
\hline 16 & 300420 - Antibiotics not elsewhere specified, in dosage & Netherlands & 3 \\
\hline 17 & 300439 - Hormones not elsewhere specified, except contraceptives, in dosage & United States & 11 \\
\hline 18 & 300439 - Hormones not elsewhere specified, except contraceptives, in dosage & Spain & 3 \\
\hline 19 & 300440 - Alkaloids, derives, no antibiotics, hormones, in dosage & United States & 3 \\
\hline 20 & 300290 - Blood, toxins, cultures, medical use, not elsewhere specified & Germany & 11 \\
\hline 21 & 300610 - Suture materials, sterile surgical and dental goods & Germany & 4 \\
\hline 22 & 300420 - Antibiotics not elsewhere specified, in dosage & Belgium & 5 \\
\hline 23 & 300220 - Vaccines, human use & Australia & 3 \\
\hline 24 & 300290 - Blood, toxins, cultures, medical use, not elsewhere specified & United Kingdom & 14 \\
\hline 25 & 300390 - Medicaments not elsewhere specified, formulated, in bulk & Ireland & 5 \\
\hline 26 & 300290 - Blood, toxins, cultures, medical use, not elsewhere specified & United States & 6 \\
\hline 27 & 300439 - Hormones not elsewhere specified, except contraceptives, in dosage & Netherlands & 6 \\
\hline 28 & 300660 - Contraceptive preps based on hormones or spermicides & United States & 5 \\
\hline 29 & 300420 - Antibiotics not elsewhere specified, in dosage & Italy & 1 \\
\hline 30 & 300439 - Hormones not elsewhere specified, except contraceptives, in dosage & Japan & 3 \\
\hline
\end{tabular}


In the top 15 product-country combinations, 'Medicaments not elsewhere specified, in dosage' appears 12 times. These export opportunities are all classified in either Cell 6 or Cell 11, which points to the fact that there is high demand for the products concerned in these markets, but the demand is not growing sufficiently in the short and long terms. Compared with its main competitors, South Africa has an intermediately small market share in the countries in Cell 6, and an intermediately large market share in the countries in Cell 11.

Most of the European and Northern American markets are traditionally large, but the lack of any noteworthy growth in these markets could be due to the global financial crisis of 2008/2009 and the subsequent economic slowdown in Europe in the wake of the eurozone crisis.

Apart from those assigned to Cells 6 and 11, many of the export opportunities in the top 50 are classified in Cells 5, 10, and 15. These are large markets, indicating growth in the short and long terms, and they might be considered to be the most lucrative markets to target for export promotion purposes.

Cuyvers et al., (1995, p. 183) and Cuyvers (1997, pp. 14-15; 2004, p. 270) suggested that the markets classified in Cells 11 to 15 should be promoted as a first priority as South Africa already has a definite comparative advantage in these markets but could grow its market share.

Table 6 sets out the pharmaceutical product-country combinations (export opportunities) that should be targeted as a first priority by export promotion organisations in South Africa. Since import demand in the productcountry combinations in Cell 11 is large but does not show any noteworthy growth, these combinations are not included in Table 6.

Table 6: Pharmaceutical Export Opportunities that should be Targeted as a First Priority

\begin{tabular}{|l|l|c|c|}
\hline $\begin{array}{c}\text { Rank Based on } \\
\text { Export Potential }\end{array}$ & \multicolumn{1}{|c|}{ HS 6-Digit Product Code and Description } & Country & Cell \\
\hline 1 & 300290 - Blood, toxins, cultures, medical use, not elsewhere specified & United Kingdom & 14 \\
\hline 2 & $\begin{array}{l}300439-\text { Hormones not elsewhere specified, except contraceptives, in } \\
\text { dosage }\end{array}$ & France & 15 \\
\hline 3 & 300220 - Vaccines, human use & Switzerland & 12 \\
\hline 4 & 300510 - Medical dressings etc. having an adhesive layer & United Kingdom & 14 \\
\hline 5 & 300590 - Medical dressings etc. except those with adhesive layer & Spain & 15 \\
\hline 6 & 300230 - Vaccines, veterinary use & Brazil & 15 \\
\hline 7 & 300590 - Medical dressings etc. except those with adhesive layer & Poland & 12 \\
\hline 8 & 300230 - Vaccines, veterinary use & Germany & 15 \\
\hline 9 & 300220 - Vaccines, human use & Sordan & 12 \\
\hline 10 & 300610 - Suture materials, sterile surgical and dental goods & Israel & 12 \\
\hline 11 & 300590 - Medical dressings etc. except those with adhesive layer & 12 \\
\hline
\end{tabular}

Vaccines for human and veterinary use and medical dressings appear more than once in the above priority list. It is interesting that, other than the European countries, Brazil, Jordan, Singapore, and Israel present first priority export opportunities.

It was shown in Section 3 that South Africa currently exports almost half of its pharmaceutical products to other countries on the African continent. These do not feature in the DSM results presented in this and the previous section because most African countries were eliminated in filter 1 of the DSM due to their excessive political and/or commercial risk, or inadequate GDP and GDP per capita size and growth rates. However, the South African government regards the strengthening of trade links with other African countries as a priority because South Africa's economic development is linked to the development of the continent as a whole (DTI, 2006). Furthermore, South Africa is the leading economy in Africa, which affords it unique trade and investment opportunities, and the country needs to retain its competitive edge in the face of the growing world-wide interest in Africa.

According to the DTI (2010), the African continent is one of the most important and fastest growing export destinations for South Africa - and for the pharmaceutical industry, particularly given its multinational character and expansionary goals. 
In view of Africa's importance to South Africa's pharmaceutical sector, the DSM process was repeated without filter 1 in order to include all African countries (assuming that exporters would be able to insure against political and commercial risk, and product-specific demand would be more important than general demand). The results of this special application of the DSM are presented in Section 5.2 below.

\subsection{Export Opportunities for South African Pharmaceutical Products in the Rest of Africa}

A total of 87 export opportunities (product-country combinations) were identified for South African pharmaceutical products in the rest of Africa.

The distribution of export potential across the different African regions is illustrated in Figure 5. It is clear that most of the potential lies in Southern Africa (48.14\%), followed by Northern Africa (18.13\%), Western Africa $(18.10 \%)$, and Eastern Africa (15.64\%).

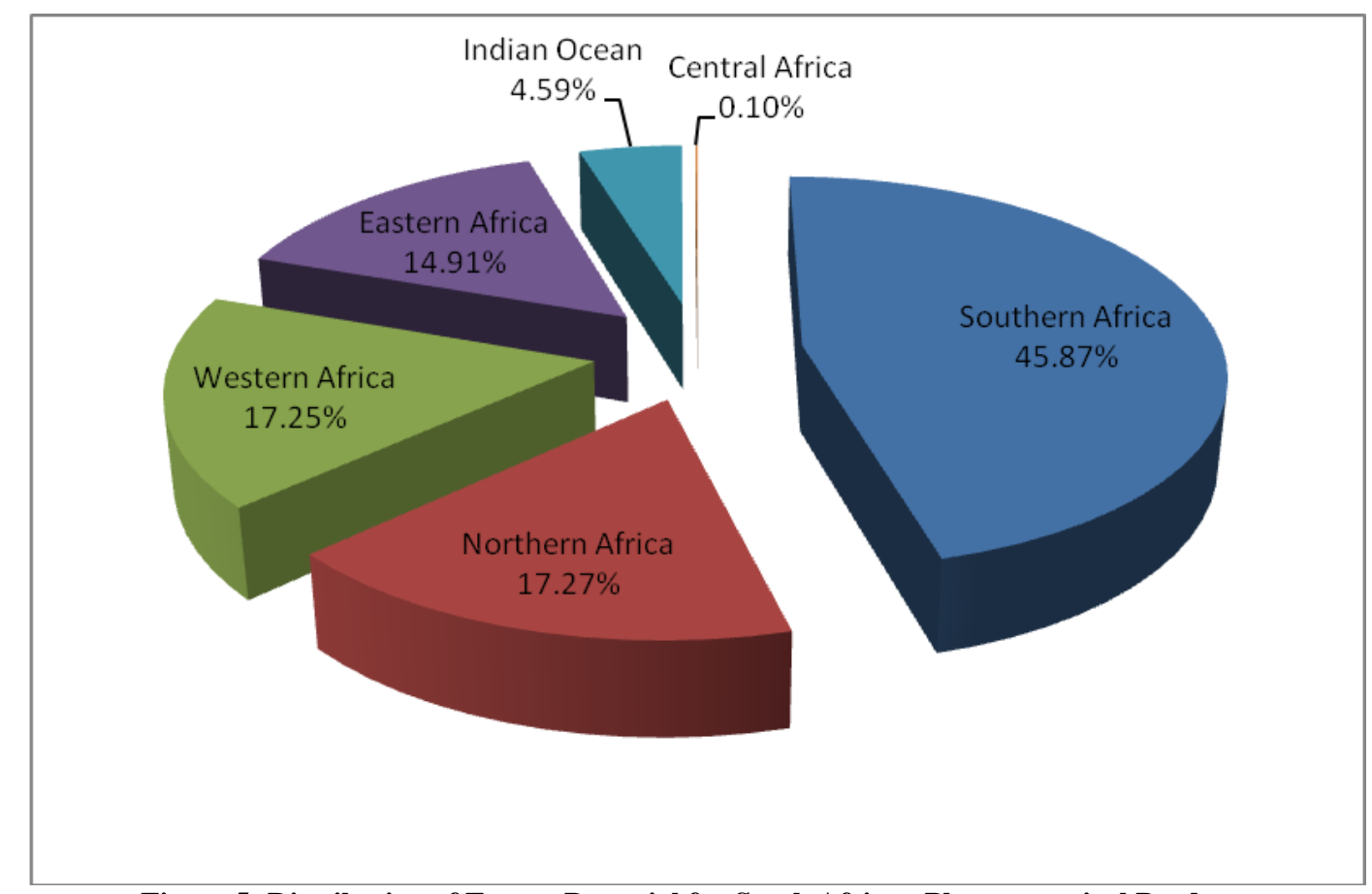

Figure 5: Distribution of Export Potential for South African Pharmaceutical Products across the Different African Regions 
Figure 6, in turn, shows the extent to which South Africa has utilised the export potential in the different African regions.

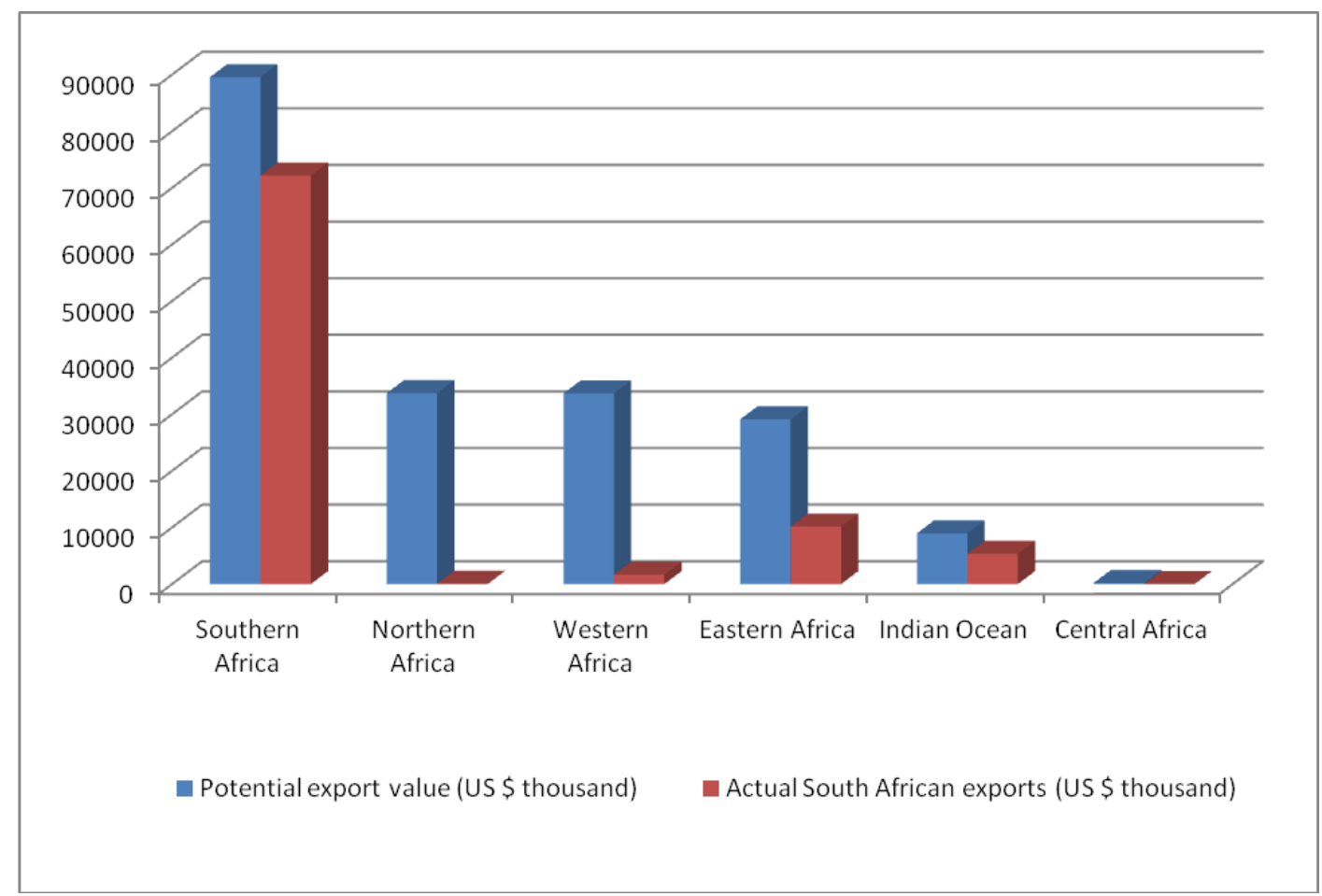

Figure 6: South Africa's Utilisation of the Export Potential for Pharmaceutical Products in the Different African Regions ${ }^{1}$

It is clear that, overall, South Africa has utilised the export potential for pharmaceutical products to a great extent in Southern Africa and the Indian Ocean countries, but has made far less headway in Northern and Western Africa. The former phenomenon might be due to South Africa's proximity to other Southern African countries and the impact of the SACU and SADC agreements.

\footnotetext{
${ }^{1}$ Table 2 shows South Africa's utilisation of the export potential for pharmaceutical products in different world regions. These regions comprise the countries that passed filter 1 of the DSM applied to identify export opportunities for South Africa in the rest of the world. In this application of the DSM, only five African countries were included, namely, Egypt and Tunisia (Northern Africa), Ghana (Western Africa), Tanzania (Eastern Africa), and Zambia (Southern Africa). When the DSM was applied to identify export opportunities for South Africa across the rest of the African continent, filter 1 was not used, and export opportunities were identified in a total of 32 African countries. This is why the figures in Table 2 do not correlate with those in Figure 6.
} 
The 20 African countries with the highest export potential for South African pharmaceutical products are shown in Figure 7, along with South Africa's utilisation of the export potential in each of these countries.

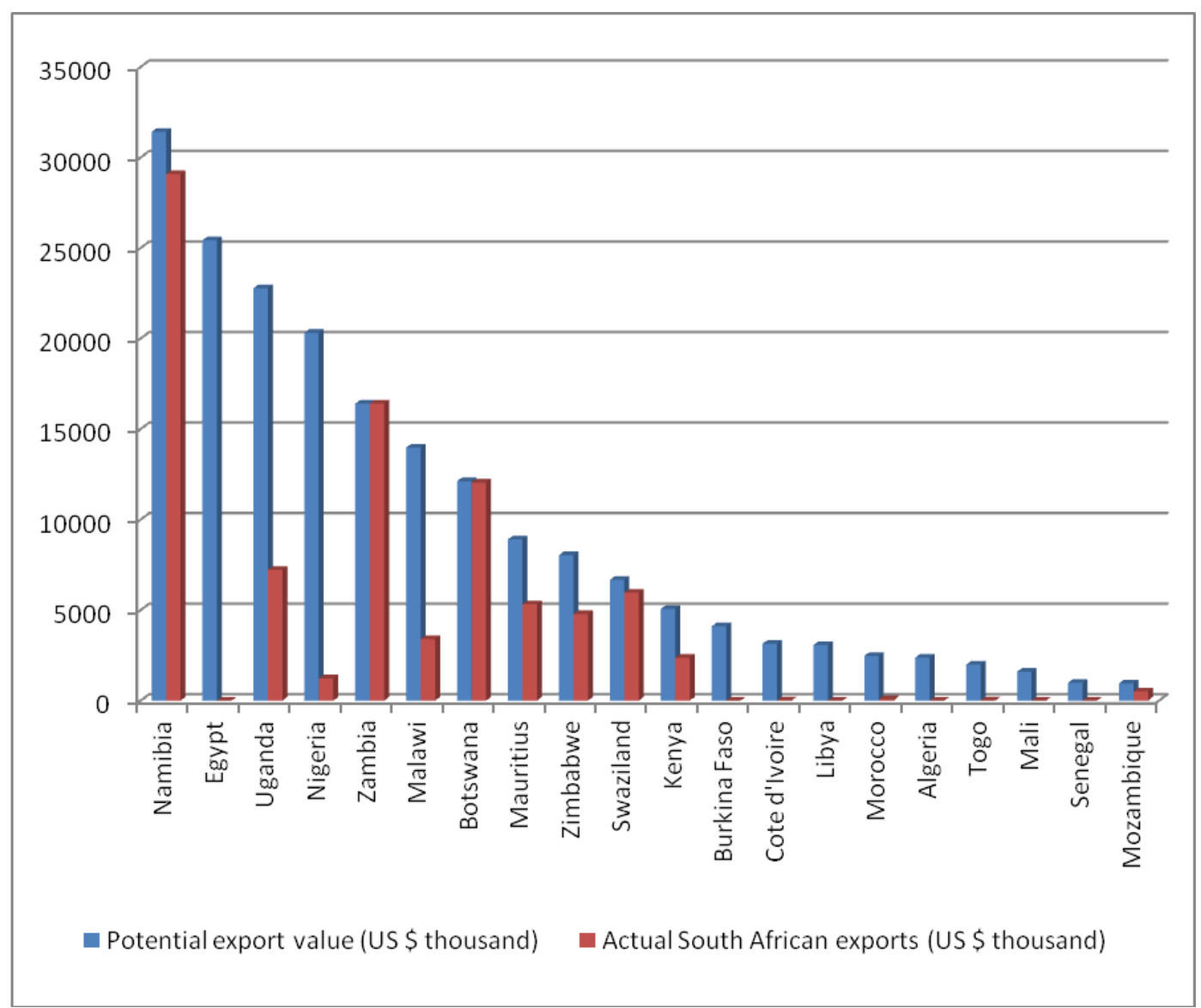

Figure 7: Top 20 African Countries in Terms of Export Potential for South African Pharmaceutical Products

The 10 African countries with the highest export potential for South African pharmaceutical products are mainly found in Southern Africa, with the exception of Egypt (Northern Africa), Uganda (Eastern Africa), Nigeria (Western Africa), and Mauritius (Indian Ocean countries).

Although Egypt holds the second largest export potential for South African pharmaceutical products, South Africa has not tapped this potential at all. Again, South Africa might have exported pharmaceutical products to Egypt before, but not those that were identified as having high export potential. It is also noteworthy that South Africa's utilisation of export potential has been very low in most other Northern African countries in the top 20. 
The pharmaceutical products with the highest export potential across the rest of the African continent, and South Africa's utilisation of this potential, are shown in Figure 8.

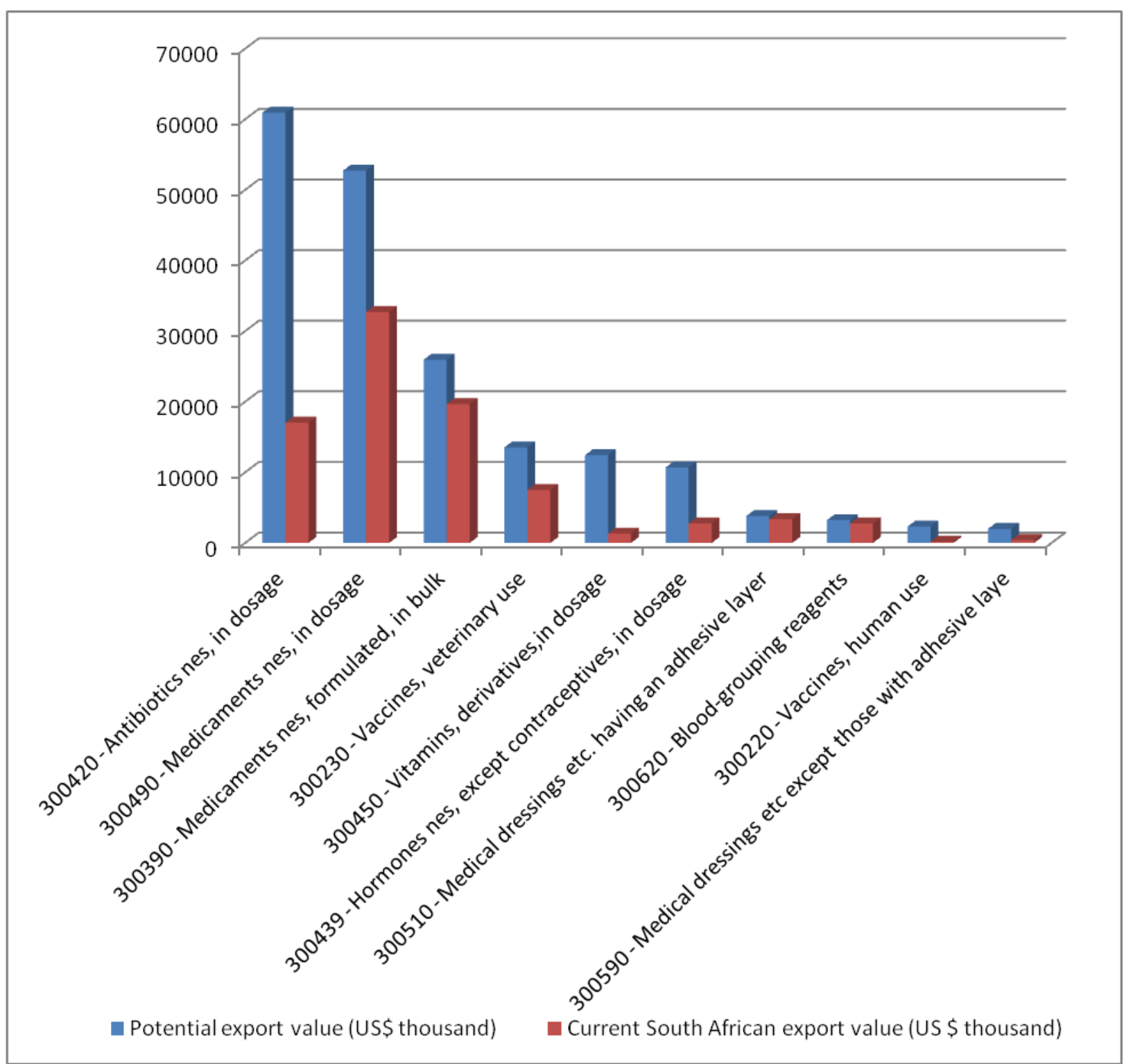

Figure 8: Top 10 Pharmaceutical Products in Terms of Export Potential for South Africa in the Rest of Africa

'HS 300420 - Antibiotics not elsewhere specified, in dosage' and 'HS 300490 - Medicaments not elsewhere specified, in dosage' hold by far the highest export potential for South Africa on the rest of the African continent. Medicaments in bulk, vaccines for veterinary use, vitamins, and hormones also hold relatively high potential for South Africa.

In most cases, the export potential has been utilised to a large extent. Exceptions, however, are 'HS 300220 - Vaccines, human use,' 'HS 300450 - Vitamins, derivatives, in dosage,' and 'HS 300590 - Medical dressings etc. except those with adhesive layer,' where the utilisation rate is less than $20 \%$. 
Table 7 ranks the $21^{2}$ pharmaceutical products included in this study according to their export potential for South Africa in the rest of Africa, and shows the extent to which South Africa has utilised the potential of each product.

Table 7: Ranking of South African Pharmaceutical Products in Terms of Export Potential in the Rest of Africa

\begin{tabular}{|c|c|c|}
\hline $\begin{array}{c}\text { Rank } \\
\text { Based on } \\
\text { Export } \\
\text { Potential }\end{array}$ & HS 6-Digit Product Code and Description & $\begin{array}{c}\% \\
\text { Utilisation of } \\
\text { Export } \\
\text { Potential by } \\
\text { South Africa }\end{array}$ \\
\hline 1 & 300420 - Antibiotics not elsewhere specified, in dosage & $27.96 \%$ \\
\hline 2 & 300490 - Medicaments not elsewhere specified, in dosage & $62.04 \%$ \\
\hline 3 & 300390 - Medicaments not elsewhere specified, formulated, in bulk & $75.81 \%$ \\
\hline 4 & 300230 - Vaccines, veterinary use & $55.43 \%$ \\
\hline 5 & 300450 - Vitamins, derivatives, in dosage & $10.61 \%$ \\
\hline 6 & 300439 - Hormones not elsewhere specified, except contraceptives, in dosage & $25.79 \%$ \\
\hline 7 & 300510 - Medical dressings etc. having an adhesive layer & $87.97 \%$ \\
\hline 8 & 300620 - Blood-grouping reagents & $85.15 \%$ \\
\hline 9 & 300220 - Vaccines, human use & $7.47 \%$ \\
\hline 10 & 300590 - Medical dressings etc. except those with adhesive layer & $20.70 \%$ \\
\hline 11 & 300320 - Antibiotics not elsewhere specified, formulated, in bulk & $18.41 \%$ \\
\hline 12 & 300610 - Suture materials, sterile surgical and dental goods & $15.86 \%$ \\
\hline 13 & 300440 - Alkaloids, derives, no antibiotics, hormones, in dosage & $1.66 \%$ \\
\hline 14 & 300660 - Contraceptive preps based on hormones or spermicides & $32.45 \%$ \\
\hline 15 & 300290 - Blood, toxins, cultures, medical use, not elsewhere specified & $12.96 \%$ \\
\hline 16 & 300339 - Hormones not elsewhere specified, no antibiotics, in bulk, not contraceptive & $85.98 \%$ \\
\hline 17 & 300670 - Gel preparations designed to be used in human/veterinary medicine as a lubricant... & $18.46 \%$ \\
\hline 18 & 300650 - First-aid boxes and kits & $24.47 \%$ \\
\hline 19 & 300340 - Alkaloids, derives, without antibiotics, hormones, in bulk & $100.00 \%$ \\
\hline 20 & 300630 - Opacifying preparations, $\mathrm{x}$-ray, diagnostic reagents & $0.00 \%$ \\
\hline 21 & 300120 - Extracts of glands etc. for therapeutic use & $100.00 \%$ \\
\hline
\end{tabular}

It is interesting to note from Table 7 that the export potential for 'HS 300340 - Alkaloids, ... in bulk' (ranked $19^{\text {th }}$ ) has been fully utilised, while only $1.66 \%$ of the potential of 'HS 300340 - Alkaloids, ... in dosage' (ranked $13^{\text {th }}$ ) has been utilised. This highlights an opportunity to package the product in dosage, and utilise this unexplored export potential for a product that is already being successfully produced and exported. The same argument applies in the case of 'HS 300339 - Hormones, ... in bulk' $\left(85.98 \%\right.$ utilisation, ranked $16^{\text {th }}$ in terms of export potential) and 'HS 300439 Hormones, ... in dosage' $\left(25.79 \%\right.$ utilisation, ranked $6^{\text {th }}$ in terms of export potential).

\footnotetext{
${ }^{2}$ HS 300190 Heparin salts for therapeutic use was not identified as an export opportunity in any African country and therefore only 21 products remain in Table 7.
} 
Table 8 sets out the product-country combinations with the highest export potential in Africa.

Table 8: Top 30 African Pharmaceutical Product-Country Combinations in Terms of Export Potential for South Africa

\begin{tabular}{|c|c|c|c|}
\hline $\begin{array}{c}\text { Rank Based } \\
\text { on Export } \\
\text { Potential } \\
\end{array}$ & HS 6-Digit Product Code and Description & Country & Cell \\
\hline 1 & 300420 - Antibiotics not elsewhere specified, in dosage & Egypt & 2 \\
\hline 2 & 300420 - Antibiotics not elsewhere specified, in dosage & Namibia & 17 \\
\hline 3 & 300490 - Medicaments not elsewhere specified, in dosage & Zambia & 17 \\
\hline 4 & 300490 - Medicaments not elsewhere specified, in dosage & Uganda & 17 \\
\hline 5 & 300390 - Medicaments not elsewhere specified, formulated, in bulk & Botswana & 17 \\
\hline 6 & 300450 - Vitamins, derivatives, in dosage & Nigeria & 17 \\
\hline 7 & 300420 - Antibiotics not elsewhere specified, in dosage & Nigeria & 17 \\
\hline 8 & 300490 - Medicaments not elsewhere specified, in dosage & Zimbabwe & 17 \\
\hline 9 & 300490 - Medicaments not elsewhere specified, in dosage & Malawi & 17 \\
\hline 10 & 300490 - Medicaments not elsewhere specified, in dosage & Mauritius & 17 \\
\hline 11 & 300230 - Vaccines, veterinary use & Namibia & 17 \\
\hline 12 & 300390 - Medicaments not elsewhere specified, formulated, in bulk & Uganda & 17 \\
\hline 13 & $\begin{array}{l}300439 \text { - Hormones not elsewhere specified, except contraceptives, in } \\
\text { dosage }\end{array}$ & Malawi & 17 \\
\hline 14 & 300390 - Medicaments not elsewhere specified, formulated, in bulk & Swaziland & 17 \\
\hline 15 & $\begin{array}{l}300439 \text { - Hormones not elsewhere specified, except contraceptives, in } \\
\text { dosage }\end{array}$ & Kenya & 17 \\
\hline 16 & 300420 - Antibiotics not elsewhere specified, in dosage & Burkina Faso & 2 \\
\hline 17 & 300510 - Medical dressings etc. having an adhesive layer & Namibia & 17 \\
\hline 18 & 300420 - Antibiotics not elsewhere specified, in dosage & Cote d'Ivoire & 2 \\
\hline 19 & 300230 - Vaccines, veterinary use & Morocco & 12 \\
\hline 20 & 300220 - Vaccines, human use & Togo & 2 \\
\hline 21 & 300230 - Vaccines, veterinary use & Algeria & 2 \\
\hline 22 & 300390 - Medicaments not elsewhere specified, formulated, in bulk & Namibia & 17 \\
\hline 23 & 300440 - Alkaloids, derives, no antibiotics, hormones, in dosage & Libya & 2 \\
\hline 24 & 300620 - Blood-grouping reagents & Malawi & 17 \\
\hline 25 & 300620 - Blood-grouping reagents & Namibia & 17 \\
\hline 26 & 300420 - Antibiotics not elsewhere specified, in dosage & Swaziland & 17 \\
\hline 27 & 300590 - Medical dressings etc. except those with adhesive layer & Uganda & 2 \\
\hline 28 & 300390 - Medicaments not elsewhere specified, formulated, in bulk & Mali & 2 \\
\hline 29 & 300320 - Antibiotics not elsewhere specified, formulated, in bulk & Namibia & 17 \\
\hline 30 & 300420 - Antibiotics not elsewhere specified, in dosage & Egypt & 2 \\
\hline
\end{tabular}

Again, it is 'HS 300420 - Antibiotics not elsewhere specified, in dosage' and 'HS 300490 - Medicaments not elsewhere specified, in bulk' that mainly feature in the top 10 African pharmaceutical export opportunities for South Africa. Furthermore, 14 of the top 30 export opportunities for the South African pharmaceutical industry are located in Southern Africa. Namibia, Malawi, and Uganda appear most frequently in the top 30, and the products making up this list are mostly drawn from the top 10 appearing in Figure 8.

From Table 8 it is evident that most of the top 30 export opportunities (product-country combinations) for the South African pharmaceutical industry in the rest of African are classified in either Cell 2 or Cell 17. This means that the demand for the specific products in the countries concerned is growing in the short and long term, but is not considered high. Those export opportunities classified in Cell 2 have in most cases not been utilised at all; yet when it comes to the opportunities classified in Cell 17, South Africa has a large market share compared with the top six competitors in each market.

If one compares the top 30 world-wide export opportunities listed in Table 5 with the top 30 export opportunities in the rest of Africa listed in Table 8, it is evident that while most of the top 30 world-wide export 
opportunities are located in Cell 6 or 11 (not growing but large import markets), most of the top 30 African export opportunities are located in Cells 2 and 17 (growing but not large import markets).

'HS 300230 - Vaccines, veterinary use' to Morocco is the only export opportunity for the South African pharmaceutical industry across the rest of the African continent that is not classified in either Cell 2 or Cell 17. It is assigned to Cell 12, which indicates that this is a growing, but not large import market in which South Africa has established an intermediately high market share compared with its main competitors in the market. This opportunity can also be explored as a first priority (see also Table 6 and the ensuing discussion).

\section{CONCLUSIONS AND RECOMMENDATIONS}

The need to accelerate South Africa's industrialisation process and diversify its exports towards more value-added manufactured goods is a common theme running through the government's key strategy documents and official statements.

The pharmaceutical industry plays a pivotal role in the South African economy as a manufacturer and exporter, and is facing growing demand for its products, particularly in the Southern African region. However, the export community on its own cannot easily exploit the opportunities that await them in foreign markets. The advice, practical assistance and financial support given to exporters by South Africa's export promotion organisations are key elements in the quest to extend the country's international footprint and improve its competitiveness. Yet the difficulty of selecting the right markets, and the capacity and resource constraints of export promotion organisations conspire to make export market development a challenging exercise - particularly for new and/or inexperienced exporters.

The Decision Support Model (DSM) has, following various applications and revisions, proved itself to be an innovative and practical market selection tool that brings a high level of precision to the business of identifying opportunities for different products in different markets. The DSM methodology was used for the purpose of this study to identify the export opportunities with the greatest potential for South Africa's pharmaceutical industry both in the world at large and, specifically, in the rest of Africa.

Among the results were that about half of the export potential for South African pharmaceutical products lies in Western Europe, followed by North America. Other world regions, such as Central Europe, Southern Europe, East Asia, and South America, reflect progressively lower demand and opportunity, although selected countries in these regions do present interesting possibilities. Of concern is the fact that South Africa has utilised the available potential for its pharmaceutical products to a very limited extent - suggesting a huge marketing opportunity for the country's pharmaceutical producers. It is only in Southern Africa and Eastern Africa that South Africa has tapped the available potential in a significant way. Currently South Africa exports about $50 \%$ of its pharmaceutical products to the rest of Africa.

The DSM results show that, world-wide, 'HS 300490 - Medicaments not elsewhere specified, in dosage' has by far the highest export potential for South Africa. According to the cell classification of the identified export opportunities, it is noteworthy that - besides European countries - Brazil, Jordan, Singapore, and Israel are among the countries recommended as high priority export opportunities. In Africa, 'HS 300420 - Antibiotics not elsewhere specified, in dosage' and 'HS 300490 - Medicaments not elsewhere specified, in dosage' are the product categories, and Namibia and Egypt are the countries, with the highest export potential for South Africa.

The results of this study highlight the fact that producers of pharmaceutical products and other decision makers essentially have a strategic choice to make: to explore the export potential of the growing African market in which South Africa already has an established presence, or to try and extend the industry's reach into the large but generally static market environment of Europe and other developed regions where South Africa has a relatively small presence.

By adopting a focused and informed approach to export market selection, the pharmaceutical industry will be able to deliver a stronger return on investment, and South Africa's export promotion organisations will be able to act as worthy partners to the private sector in directing their resources at clear and sustainable opportunities. 


\section{AUTHOR INFORMATION}

Prof. Wilma Viviers is a research, leader of the TRADE (Trade and development) research entity and NRF rated researcher at the North-West University (NWU), Potchefstroom campus. She holds a PhD in Economics and a Certificate in Export Practice, has an impressive array of publications, and is a leading authority in the fields of export promotion, competitive intelligence (CI), and economic development. Prof. Viviers' passionate research interest in, and active contribution towards the realisation of, strategies to improve South Africa's trade performance and competitiveness, are acknowledged both locally and internationally. She has also received numerous awards in recognition of her ground-breaking research over the years. E-mail: wilma.viviers@nwu.ac.za (Corresponding author)

Prof. Martie Lubbe is currently the leader of the research niche area, Medicine Usage in South Africa (MUSA) at the North-West University (NWU), Potchefstroom campus in South Africa. Prof. Lubbe obtained her Bachelor's, MPharm and PhD degrees in Pharmacy Practice at the Potchefstroom University for CHE. She has devoted 25 years of her career to pharmacy education and practice-related research and contributed significantly towards the development of Pharmacy practice. From 2004 to 2009 she acted as Subject head of Pharmacy Practice at the NWU. E-mail: martie.lubbe@nwu.ac.za

Dr. Ermie Steenkamp is a senior lecturer in Economics and International Trade in the School of Economics and researcher within the TRADE research entity at the North-West University, Potchefstroom campus in South Africa. She has recently completed her $\mathrm{PhD}$ on identifying export opportunities for South Africa with special reference Africa. Dr. Steenkamp's research mainly focuses on international market selection, the measurement of market accessibility, and export promotion in South Africa as well as export potential analyses on a provincial and sectoral level. Another interest includes measuring the developmental impact of increased exports, especially on unemployment. E-mail: ermie.steenkamp@nwu.ac.za

Prof. Douglas Olivier is a professor in Pharmacology at the North-West University, Potchefstroom campus. He is registered with the South Africa Pharmacy Council and has served in more than 50 pharmacies in South Africa and Namibia. Prof. Oliver has obtained two doctoral degrees, one in Pharmacology and one in Pharmaceutical and Medicinal Chemistry in the fields of in vivo cerebral perfusion pharmacology and in drug discovery, respectively. Prof. Oliver has trained more than 30 doctoral and master degree students in pharmacology and pharmaceutical and medicinal chemistry and is the author of more than 100 publications and a presenter of more than 200 national and international presentations in 25 countries. E-mail: douglas.oliver@nwu.ac.za

\section{REFERENCES}

1. Adcock Ingram. (2012). Adcock Ingram. Retrieved from http://www.adcock.co.za/AboutUs_CompanyProfile.aspx

2. Aspen Holdings. (2012). Aspen South Africa. Retrieved from http://www.aspenpharma.com/default.aspx?pid=9\&stepid=1\&oid= 129

3. Bernard, A.B., Jensen, J. B., Redding, S. J., \& Schott, P. K. (2011). The empirics of firm heterogeneity and international trade. (Working Paper 17627). National Bureau of Economic Research.

4. Cuyvers, L. (1997). Export opportunities of Thailand: A decision support model approach. (CAS discussion Paper, No. 9). Retrieved from http://webhost.ua.ac.be/cas/PDF/CAS09.pdf

5. Cuyvers, L. (2004). Identifying export opportunities: The case of Thailand. International Marketing Review, 21(3), 255-278.

6. Cuyvers, L., De Pelsmacker, P., Rayp, G., \& Roozen, I. T. M. (1995). A decision support model for the planning and assessment of export promotion activities by government export promotion institutions: The Belgian case. International Journal of Research in Marketing, 12(2), 173-186.

7. Cuyvers, L., Steenkamp, E. A., \& Viviers, W. (2012). The methodology of the Decision Support Model (DSM). In L. Cuyvers, \& W. Viviers (eds), Export promotion: A decision support model approach. Stellenbosch: Sun Media Metro. 
8. Cuyvers, L., Viviers, W., Sithole, W., \& Muller, M.-L. (2012). Developing strategies for export promotion using a decision support model. In L. Cuyvers, \& W. Viviers (eds), Export promotion: A decision support model approach. Stellenbosch: Sun Media Metro.

9. Deloitte Consulting (Pty) Ltd. (2007). The economic \& socio-economic benefits of R\&D-based multinational pharmaceuticals on the South African economy. Johannesburg: Future World® powered by Deloitte.

10. Deloitte. (2010). Insights into the high-level financial contribution of the Pharmaceutical Industry in South Africa.

11. Department of Health. (2011). National health insurance in South Africa. Policy paper. Pretoria: Department of Health.

12. Dummet, H. (2002). An overview of supply and demand in South Africa's pharmaceutical industry opportunity and risk. Business Briefing: Pharmatech, 49-54.

13. DTI. see South Africa. Department of Trade and Industry.

14. Essack, S. Y., Schellack, N., Pople, T., Van der Merwe, L., Suleman, F., Meyer, J. C., Gous, A. G. S., \& Benjamin, D. (2011). Part III. Antibiotic supply chain and management in human health. South African Medical Journal, 101(8), 562-566.

15. International Trade Centre. (2012). Trade map: Trade statistics for international business development. Retrieved from http://www.trademap.org/Country_SelProduct_TS.aspx

16. Maloney, C., \& Segal, N. (2007). Genesis: The growth potential of the pharmaceutical sector in South Africa. Johannesburg: Genesis Analytics (Pty) Ltd.

17. Mdluli, A. (2012). State allocates R102bn to NGP and IPAP sectors over 5 years. Retrieved from http://www.iol.co.za/business/business-news

18. NKC. (2012). Monitoring African sovereign risk. South African Quarterly Update, March 2012.

19. Pearson, J. J. A. P., Viviers, W., Cuyvers, L., \& Naudé, W. (2010). Spotting opportunities for international entrepreneurship in the southern engines: A DSM approach. International Business Review, 19(4), 345359.

20. South Africa. Department of Trade and Industry. (2006). Draft export strategy 2006-2009: Trade and investment South Africa, export development and promotion. (Internal document, Unpublished) 101 p.

21. South Africa. Department of Trade and Industry. (2010a). The South African national industrial policy framework. The dti Campus, Pretoria.

22. South Africa. Department of Trade and Industry. (2010b). The South African trade policy and strategy framework. The dti Campus, Pretoria. 64p.

23. South Africa. Department of Trade and Industry. (2010c). A South African trade policy and strategy framework. Retrieved from http://www.thedti.gov.za/trade_policy/TPSF.htm

24. South Africa. Department of Trade and Industry. (2011). Industrial policy action plan. 2011/12-2013/13. Economic sectors and employment cluster. February 2011.

25. Steenkamp, E. A. (2011). The identification of export opportunities for South African products with special reference to Africa. (Thesis - PhD). Potchefstroom: North-West University.

26. Viviers, W., \& Pearson, J. J. A. P. (2007). The construction of a decision support model for evaluating and identifying realistic export opportunities in South Africa: report prepared for the Department of Trade and Industry, South Africa. May. (Unpublished). 92 p.

27. Viviers, W., Rossouw, R., \& Steenkamp, E. A. (2009). The sustainability of the DSM for identifying realistic export opportunities for South Africa: 2007-2008: Report prepared for the Department of Trade and Industry, South Africa. February. (Unpublished). 105 p.

28. Viviers, W., Steenkamp, E. A., \& Rossouw, R. (2010). Identification of realistic export opportunities for South Africa: application of a decision support model (DSM) using HS 6-digit level product data: report prepared for the Department of Trade and Industry, South Africa. September. (Unpublished). 57 p. 
NOTES 